\title{
Creating a University Driven "Ingepreneurial" Ecosystem in West Baltimore: A Strategy for Rust Belt Revitalization
}

Ronald C. Williams, Ph.D., and Elgin L. Klugh, Ph.D.

\begin{abstract}
The legacy of deindustrialization and associated underemployment continues to plague many former industrial communities. In these spaces, universities serve as anchors providing gateways for individual economic empowerment, and as 'brain centers' charged with generating solutions for societal problems. This paper explores the development of The Center for Strategic Ingepreneurship (CSI) at Coppin State University in Baltimore, Maryland. Strategic Ingepreneurship is seen here as a practical, innovative, solution-based approach to address underperforming job creation. The Center will serve as a university-based entity to facilitate the development and dissemination of ingepreneurial knowledge and skills through research, teaching, and practice.
\end{abstract}

\section{Keywords}

Entrepreneurship; anchor institution; socioeconomic trajectory; community engagement; deindustrialization

"There are risks and costs to action. But they are far less than the long-range risks of comfortable inaction" (John F. Kennedy, n.d.)

\section{Introduction}

Like many former industrial hubs, Baltimore City's current landscape includes communities suffering the effects of disinvestment, joblessness, poverty, crime, and an aging housing stock. These issues are particularly manifest in predominantly African American neighborhoods, where they are compounded by a history of discrimination and lower economic resiliency.

Concurrently, portions of Baltimore City are thriving as the city continues to court businesses, develop its downtown tourist industry, and emerge as a "technology hub" drawing highly educated and highly skilled workers seeking to live in the city.

The familiar result is a gentrification that creates invisible, slowly expanding lines separating domains of urban, young, metropolitan, multicultural but mostly white professionals, and predominantly African American, indigenous enclaves largely disconnected and disenfranchised from economic growth. In fact, the two worlds exist in such proximity that many have the common Baltimore experience of turning a corner or traveling one block and feeling as if they have entered a different world. 
The 2015 Baltimore uprising drew much attention to economic disparities, specifically within the context of West Baltimore. Subsequently, researchers and granting agencies increased efforts to address the range of complex social problems negatively impacting the city's poorest communities. Coppin State University (CSU) is among those entities striving to improve conditions in the community. This paper presents the CSU Center for Strategic Ingepreneurship as a strategy leveraging existing programs to address the complex social problem of underperforming job creation. Ingepreneurship - the act of infusing ingenuity into an entrepreneurship and business development process - refers to the formative structural and educational environment that nurtures successful entrepreneurship activities for those starting from positions of poverty and deprivation. This center will serve as the core of a job creating, ingepreneurial ecosystem, composed of a wide array of stakeholders committed to improving socioeconomic trajectories of West Baltimore residents.

Although economic and social measures illustrate a portrait of severe poverty, direct observation exposes the existence of an unregulated, entrepreneurial subculture that can be nurtured, legitimized, and augmented to enable job creation. The existence of an ingepreneurial ecosystem, sustained by long term, mutually aligned, centrally coordinated relationships between academia, corporations, public sector agencies, funders, mentors, and support services, will provide a venue for aspiring ingepreneurs interested in changing current socioeconomic characteristics of West Baltimore.

\section{West Baltimore}

Urban scholars have long studied the damaging effects of the shift from manufacturing to administrative and service employment in American cities (Kasarda 1989, 1992;, Wilson 1987, 1996). Cities, like Baltimore, that experienced tremendous population growth as mid-twentieth century manufacturing powerhouses, lost many of the jobs that attracted and sustained working class families. As a result, residents, who once knew industrial employment as a clear pathway to a middle-class standard of living, now lead the state in such indicators as overall poverty, child poverty, senior poverty, individuals living below 200 percent of the poverty line, residents receiving temporary cash assistance, children receiving temporary cash assistance, percentage of the population participating in food supplement programs, and the percentage of children who participate in the Free and Reduced Price Meals program (MD Alliance of the Poor, 2014).

Data specific to the two communities adjacent to Coppin State University (the Greater Rosemont and Greater Mondawmin Communities) reflect the realities of the city at large. Of concern are the high numbers of children growing up in poverty, the high number of vacant and abandoned properties, the high unemployment rate, and the significant rate of juvenile arrests for violent offenses. The primary problem is the shortage of that which facilitates socioeconomic mobility: high performing public schools and jobs. 
(Table 1)

Poverty Indicators of Greater Rosemont and Greater Mondawmin Neighborhoods

\begin{tabular}{|l|l|l|}
\hline Indicator & Greater Rosemont & Greater Mondawmin \\
\hline \% African American & 96.6 & 96.2 \\
\hline Median household income & 30,865 & 38,655 \\
\hline \% Households below poverty line & 21.7 & 14.6 \\
\hline \% Children below poverty line & 43.1 & 30.5 \\
\hline \% Vacant properties & 16.3 & 12.0 \\
\hline $\begin{array}{l}\text { Juvenile arrests for violent offenses } \\
\text { per 1,000 residents }\end{array}$ & 21.6 & 22.0 \\
\hline Unemployment rate & 22.2 & 20.6 \\
\hline High School completion rate & 79.0 & 88.4 \\
\hline
\end{tabular}

(Baltimore Neighborhood Indicators Alliance, http://bniajfi.org)

As part of the Equality of Opportunity Project, Chetty, Hendren, Kline, \& Saez (2014) explore factors correlated with intergenerational mobility. Specifically, they find that " $[\mathrm{h}]$ igh mobility areas have (1) less residential segregation, (2) less income inequality, (3) better primary schools, (4) greater social capital, and (5) greater family stability" (p. 1). Given the statistical characteristics cited in Table 1, it may not be surprising that, when calculating the percentage gain/losses of adulthood earnings for children in low-income families relative to growing up in an average place, Baltimore City ranks at the bottom of the list of one hundred (100). More specifically, for "children growing up in families at the 25 th percentile of the national income distribution" each additional year in Baltimore City appears to have a $-0.86 \%$ impact on adulthood earnings (Chetty \& Hendren, 2015). This is particularly relevant for communities immediate to CSU wherein high numbers of children are growing up beneath the poverty line.

Concentrated disadvantage experienced by West Baltimore residents can be quantified on the neighborhood level in many ways (i.e. intergenerational mobility, levels of unemployment, availability of healthy food options, number of liquor stores, crime rates, or housing values). Due to its direct impact on quality of life in the community, and the availability of data, crime has been a central focus of such discussions. Criminological literature presents empirical support of the relation between concentrated disadvantage and crime (Krivo and Peterson 2000; M. R. Lee and Ousey 2005; Parker 2004; Parker and McCall 1999). In her research, however, Karen Parker (2015) explores issues of concentrated disadvantage and crime by investigating the correlation between African American entrepreneurship and youth violence.

Parker (2015, p. 21) reports:

[W]e find that the presence of Black business was a significant predictor of the change in Black youth violence between 1990 and 2000, but the growth in Black firms with paid employees did not significantly contribute to the change in youth violence over time. Thus, we find additional support in our temporal models that actual employment appears less significant to Black youth violence than the 
cultural component that comes with the growing presence of Black-owned businesses in U.S. cities. That is, Black businesses serve an important function as role models and source of mainstream culture to urban youth in the community.

These findings indicate that a simple numerical increase in the number of jobs does not automatically cause a decrease in youth violence. Rather, shifts in the cultural environment engendered by the presence of African American-owned businesses proved to have tangible and intangible benefits that should be further explored.

Parker's findings concerning the impact of African American-owned businesses is highly relevant to West Baltimore. Prior to integration, West Baltimore was renowned as a business and cultural mecca for African Americans. Unfortunately, the advent of integration occurred as deindustrialization was actively eliminating the blue-collar jobs that sustained local businesses. Collectively, these forces dispersed and economically depressed a once captive population, greatly contributing to the current situation wherein low levels of African American business ownership are correlated with high levels of youth violence.

West Baltimore residents seeking to finance business ventures have historically faced challenges in obtaining institutional support. During segregation, formal institutional lending was largely unavailable to the African American entrepreneur. This created a tenuous situation for business owners, resulting in higher rates of failure. At that time, in lieu of, or in addition to, personal and family capital, the West Baltimore resident with an idea could turn to the likes of William Adams (a.k.a. Little Willie), the head of a local numbers running operation. He generously supported entrepreneurs, due to his desire for a stronger and more economically resilient African American community (Cheshire 2016, p. 93). Today, institutional lending is much more available; however, individuals starting from positions of poverty still face structural barriers that result in an over-dependence on personal capital and a weakened resiliency.

Discussing the current state of African American business owners, Parker (2015, p. 23) writes:

These business owners are largely dependent on their own personal or family capital for start-up funds, where their access to external capital relative to nonminority-owned businesses is significantly limited (Bates 1993; Boyd 1991; Butler 1991). This often leads to higher rates of failure among minority-owned businesses, which will only continue to fail at higher rates without greater institutional support. Understanding this reality and the racial discrimination that shape it are critical to overcoming this structural barrier. Furthermore, in more practical terms, providing assistance to minority-owned businesses, such as technical training, information on how to seek out loans, programs on how to run a business, developing accounts, and building assets, could reduce barriers faced by minorities when seeking financial capital or start-up funds (see also Robb \& Fairlie 2009).

Parker's suggestions for reducing structural barriers to African American entrepreneurship are in-line with the vision and goals of the Center for Strategic Ingepreneurship. Additionally, the 
potential positive impacts for the community would add to Coppin State University's efforts to effect quality of life improvements for residents of West Baltimore communities.

\section{Coppin State University as a West Baltimore Community Anchor}

Coppin State University has a strong history of service to the West Baltimore community. From its early twentieth century beginnings as a training academy for African American teachers, to its present status as a comprehensive university with a variety of undergraduate and graduate program offerings, the institution has prioritized community engagement and service.

Like many urban universities, a stated commitment to community engagement is weaved into CSU's mission statement and institutional objectives. The mission statement proclaims CSU as an anchor institution "committed to community engagement" (CSU Mission Statement, n.d., para. 2). In June 2014, the City of Baltimore formally acknowledged CSU's role as a community anchor in The Baltimore City Anchor Plan: A Community and Economic Development Strategy. CSU was also recognized by the United States Department of Housing and Urban Development (HUD) as a leading HBCU demonstrating best practices "in implementing community and economic development activities in low-wealth communities in the same year (https://www.huduser.gov/register/hbcu_anchors.html).

\section{(Figure 1)}

City of Baltimore 2014, p. 4

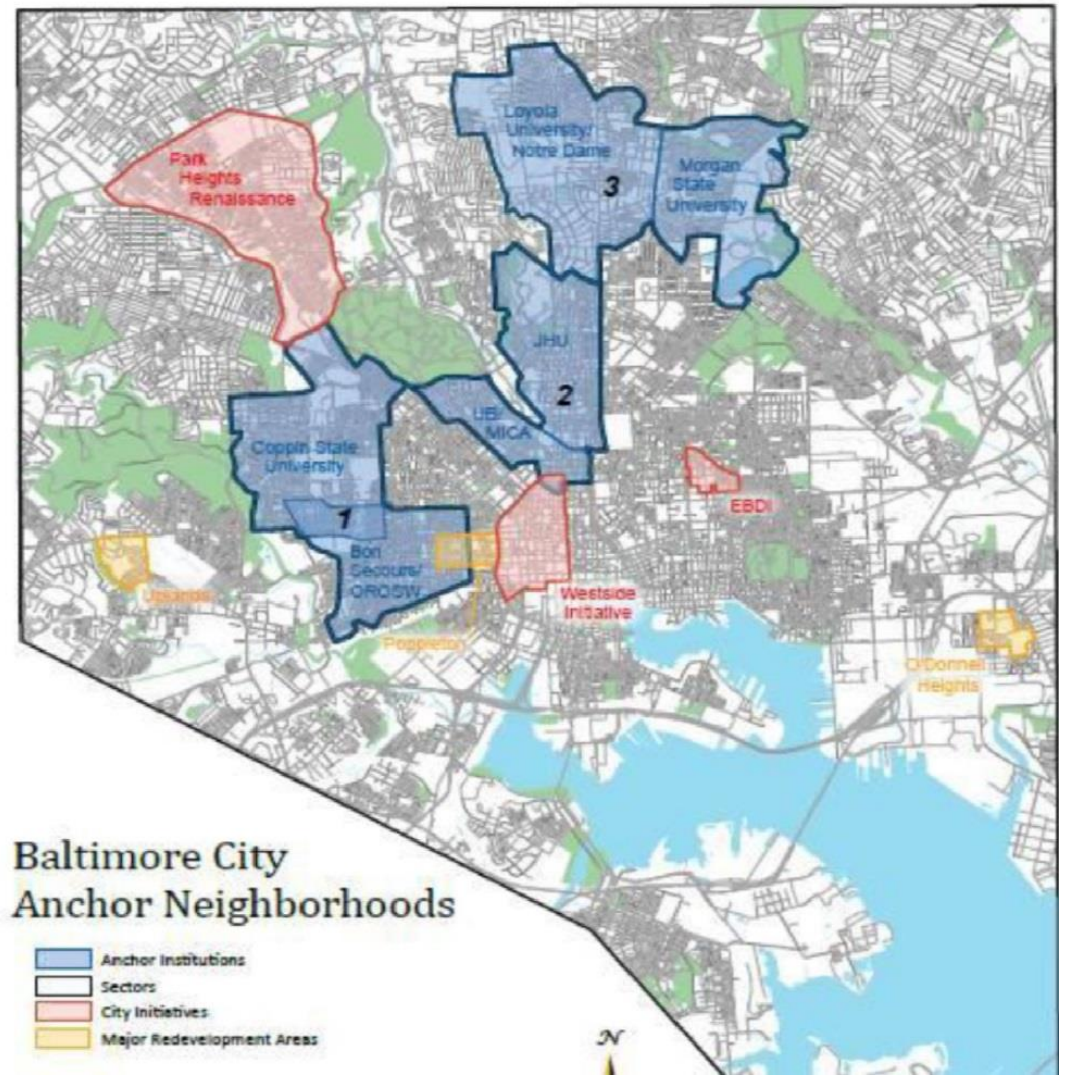


A major community engagement initiative has been the CSU Urban Education Corridor. The goal of the corridor is to create a pipeline of educational opportunity that can potentially support students from preschool through the doctoral degree. To this end, CSU operates a preschool on campus, maintains a partnership with Rosemont Elementary/Middle School, and operates the Coppin Academy High School on the CSU campus. Reportedly, Rosemont Elementary/Middle is now "one of the highest achieving schools in the State of Maryland," and Coppin Academy "is the highest achieving non-selection high school in the City of Baltimore" (http://www.coppin.edu/schoolofeducation/uec). Other community engagement efforts include collaboration with the Coppin Heights Community Development Corporation (Rodwell \& Klugh, 2014), partnerships with local healthcare agencies, and a host of other activities coordinated and performed by CSU employees and students as representatives of the university.

Through various initiatives, CSU strives to be an institution that integrates community engagement efforts in its operations in a way that develops human capital in the surrounding community. This is particularly important in a community wherein concentrated disadvantage prevents so many individuals from financial and educational achievement. From the perspective of institutional competitiveness, CSU's community engagement efforts also work to mitigate an unfavorable environment that could serve as a detriment in recruiting students, staff and faculty.

CSU currently enrolls a student population close to three thousand. This population is over eighty percent (80\%) African American, almost fifty-percent (50\%) residents of Baltimore City, and largely in need of financial assistance (Coppin State University 2013 - 2020 Strategic Plan, p.8). Geographically, CSU sits within a financially challenged community that is over ninetypercent (90\%) African American. However, a synergistic relationship between the university and the community cannot be taken for granted; although there are significant grounds for racial and economic solidarity (Klugh, 2016). As such, CSU strives to actualize Gavazzi's (2015) definition for a "harmonious type" town-gown relationship, "defined by the relatively high amount of activity that is directed toward the pursuit of goals that are of shared benefit to the campus and community" (p. 149).

The university's slogan, "Nurturing Potential, Transforming Lives," speaks to the critical function that the university performs in uplifting the knowledge, skills, and abilities of its students, several of whom come from Baltimore's poorest communities. Given its location, student population, and existing community engagement efforts, CSU is well-positioned to advance an ingepreneurial ecosystem. Existing K-12 education and community partnerships provide avenues to involve West Baltimore residents within a broader network inclusive of business and public sector resources, academia, and other support services that, together, can cultivate cohorts of aspiring ingepreneurs. On the individual level, opportunities for financial education and economic empowerment will greatly improve socioeconomic trajectories. On the community level, cultivating a critical mass of aspiring ingepreneurs can potentially deconcentrate disadvantage and affect cultural shifts to improve attitudes, perception, and overall quality of life in the community.

\section{A Case for a Diverse "Ingepreneurial" Ecosystem}


Ingenuity is the ability to approach rapidly evolving complexities in unique ways while producing marketable products and services. The emphasis is on encouraging freedom of thought and process with a goal of achieving marketability. The solution to the under-performing job creation and education systems depends on the development of a system of strategic "ingepreneurship." Ingepreneurship, a term coined by Ronald C. Williams, is the act of infusing ingenuity into an entrepreneurship and business development process. While $20^{\text {th }}$ century theorist such as Joseph Schumpeter, Carl Menger, Ludwig von Mises and others were advocates of innovation in creating new industries, the concept of ingepreneurship is informed by their work and calls for an even greater emphasis on structural opportunities that foster ingenuity. Structural opportunities are evident in the need for "wraparound" support that facilitates vibrant innovation. Wraparound has been defined as "an intensive, holistic method of engaging with individuals with complex needs (most typically children, youth, and their families) so that they can live in their homes and communities and realize their hopes and dreams." (Regional Research Institute, School of Social Work, Portland State University, 2017) The traditional processes of entrepreneurship and business development involve a progression from opportunity recognition to exit or expansion (Table 2). However, these clearly defined steps fail to address the complex social needs of many who are attempting to navigate the road to successful entrepreneurship from positions of extreme poverty or socioeconomic deprivation.

Opportunity for engagement is key in the process of building a robust ingepreneurial ecosystem. Engagement should begin early in the educational process and reach into all segments of the community. Relationships with a variety of institutions within the community are also essential. Families, religious institutions, financial institutions, community organizations, and businesses are necessary to build an environment that will nurture the potential of emerging ingepreneurs.

\begin{tabular}{|cl|}
$\begin{array}{l}\text { Stages of } \\
\text { (Table 2) }\end{array}$ & Entrepreneurship and Business Development \\
\hline$\bullet$ & Idea or Opportunity Recognition \\
\hline$\bullet$ & Planning \\
\hline$\bullet$ & Resource Identification \\
\hline$\bullet$ & Launch \\
\hline$\bullet$ & Growth \\
\hline$\bullet$ & Adaptation and Opportunity Exploration \\
\hline$\bullet$ & Exit or Expansion \\
\hline
\end{tabular}

(Entrepreneurial Life Cycle, 2015)

It is important to note that all ingepreneurs are entrepreneurs, but not all entrepreneurs are ingepreneurs. Ingepreneurs engage in the activities that define them as entrepreneurs; but the primary difference in their activities is related to the extent to which inventiveness is encouraged, valued, and expected while building environmental supports to address issues such as housing, healthcare, personal finance, and hunger as quality of life concerns. Ingepreneurs are naturally excited about the creative process, and the creative process is meant to be a collaborative 
process. Ingepreneurs also understand that new businesses are birthed and ultimately grow in climates of unrestricted creativity. Therefore, an ingepreneur is:

a person who engages in entrepreneurial activity with an emphasis on the innovative aspects of enterprise development while infusing creativity into every phase of the entrepreneurial, business development process. Ingepreneurs demonstrate a concern for influencing the socioeconomic trajectory of members of a select geographic or demographic community.

Strategic ingepreneurship integrates entrepreneurship and ingepreneurship through a process of educational and practical experiences. The experiences utilize a collaborative process of "playful ingenuity" (Hewing, 2014). This type of free-wielding, collaborative engagement is integrated into each stage in the entrepreneurial process to encourage exploration of a broad range of options for providing products and services to consumers. The process turns playful ingenuity into purposeful practices for entrepreneurial profit.

Ingepreneurial socialization is one of the objectives of strategic ingepreneurship. Strategic ingepreneurship is most valuable in the context of deep socioeconomic disadvantages. It is the process by which members of impoverished communities become proficient in methods of socioeconomic advancement generated by personal ingenuity. Moving members of economically depressed communities from unregistered to registered economic opportunities will require significant cultural training, education, and development. Members of such communities have often lacked exposure to opportunities that would provide knowledge of the fundamentals of business start-up and growth. Therefore, the successful model for strategic ingepreneurship will include three basic elements:

- Socioeconomic Trajectory

- Entrepreneurship

- Playful Ingenuity

It is also important to recognize the necessity for diversity in developing ingepreneurial systems. Diversity does not only occur by way of inclusion of all stakeholders within an urban community. For the purposes of this introduction to ingepreneurial systems, it is important to bring attention to the value of familiarizing those in urban areas with the socioeconomic realities of those in rural areas (Myers, 2001). Those in urban areas will benefit by knowing that socioeconomic disparities resulting from de-industrialization are not just urban issues. Those in rural areas will benefit by becoming familiar with the elements of urban economic realities. The inter-regional ingepreneurial exchange will assist in changing perspectives and broadening views of socioeconomic deprivation. The centralized location of Baltimore provides opportunities to exchange and interact with rural communities that share socioeconomic commonalities with urban communities. The differentiating factors in many cases are limited to the concentration of African Americans in urban communities and the concentration of non-African Americans in 
rural communities. The factors that have led to the conditions and the consequences are often the same.

\section{The Center for Strategic Ingepreneurship (CSI)}

CSU currently delivers many programs involving community engagement and development. Improving the delivery of the programs and solidifying the CSU's position as the nucleus of a university-based innovation hub requires the implementation of a structural framework in which these existing programs reside and are presented to the community. The Center for Strategic Ingepreneurship (CSI) will serve as a university-based entity that will facilitate the development and dissemination of ingepreneurial knowledge and skills through research, teaching, and practice. Serving as the nucleus of ingepreneurial activities across the campus of Coppin State University, the center will increase the understanding of ingepreneurial activity in urban settings, while using the modified entrepreneurial concept as its framework. CSI will certainly share some commonalities with university-based entrepreneurship centers, particularly those in urban, deindustrialized areas. However, the uniqueness in the CSI's mission is consistent with the distinct identity of Coppin State University and the environmental realities of West Baltimore. The University's "Institutional Identity Statement" describes the school as "a Historically Black Institution (HBI) within the University System of Maryland that prepares students with the mission of meeting the challenges associated with urban communities" (CSU Mission Statement, 2015). The center's primary target population includes members of the West Baltimore community, Baltimore City Public School System students, graduates of Baltimore City and Baltimore County Public School Systems, and Coppin State University students and stakeholders. The organic framework represented in the ingepreneurial ecosystem will enable CSI to assist in preparing constituents to return to their communities as socioeconomic change agents by infusing the community with knowledgeable and skillful job creators and innovators who are familiar with its unique challenges.

(Figure 2)

Ingepreneurial Ecosystem 


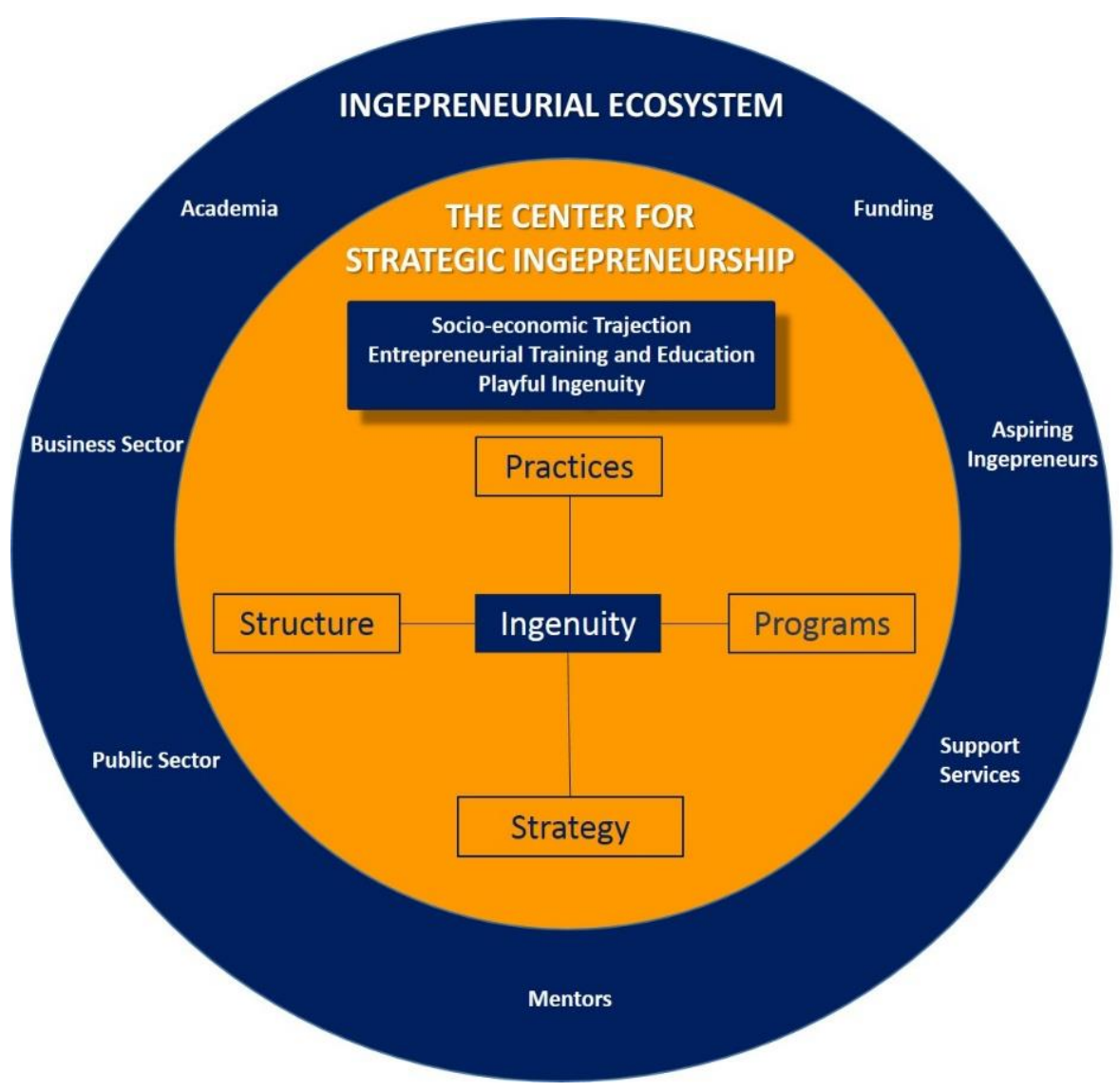

As the nucleus of ingepreneurship initiatives across campus, the CSI will provide direction across disciplines and advocate for multi-disciplinary approaches to business development. Coppin State University provides a diverse array of academic programs in business, healthcare, science, technology, social science, art, and humanities that are conducive to interdisciplinary 


\begin{tabular}{|c|c|}
\hline & $\begin{array}{l}\text { sed Strategic Ingepreneurship } \\
\text { ammatic Emphasis (Table 3) }\end{array}$ \\
\hline & I Trajectory \\
\hline - & Banking Services \\
\hline - & Understanding Credit \\
\hline$\bullet$ & Basics of Investing \\
\hline - & Home Ownership \\
\hline$\bullet$ & Community Engagement \\
\hline$\bullet$ & Educational Options \\
\hline$\bullet$ & Career Development \\
\hline & preneurship \\
\hline - & Business Plan Competitions \\
\hline & $\begin{array}{l}\text { Certificate Programs (Youth, } \\
\text { Academic Community, Business } \\
\text { Community) }\end{array}$ \\
\hline$\bullet$ & Pipeline Programs (K through 12) \\
\hline - & Incubator Program \\
\hline & Start Up Conference \\
\hline & $\begin{array}{l}\text { Summer Ingepreneurship } \\
\text { Academies }\end{array}$ \\
\hline - & $\begin{array}{l}\text { Exchange Programs (Urban Rural } \\
\text { Initiative) }\end{array}$ \\
\hline$\bullet$ & Pitch Competitions \\
\hline - & Executive Certificate Programs \\
\hline & Speaker Series \\
\hline & CSI Alumni \\
\hline & Technological Ingepreneurship \\
\hline & Collaborative Research \\
\hline & Publications \\
\hline & Workforce Development Initiative \\
\hline & Internships \\
\hline & Annual Conference \\
\hline & ul Ingenuity \\
\hline & Play 2 Profit Forums \\
\hline & Collaboration in the Clouds \\
\hline
\end{tabular}

approaches to ingepreneurial development. The multi-disciplinary approach will provide opportunities that transcend industries and infuse ingenuity into all areas of interest.

One of the barriers to ingepreneurship is the individual organizations' lack of sufficient resources to provide wraparound support, entrepreneurship education, and space availability. Comprehensive ingepreneurial development requires community collaboration. Organizations that provide "participative spaces" (Davies et al.) for emerging ingepreneurs are one of the greatest contributors to the development the ingepreneurial ecosystem. Open Works Baltimore is one example of a provider of participative space and collaboration. Open Works is a makerspace that provides affordable membership access to a plethora of tools, technology, workshops, and expert staff (http://openworksbmore.com). Open Works and Coppin State University entered into an unprecedented agreement in 2016 making Coppin the first public HBCU to have a formal agreement providing: (1) opportunities for students to interact with and mentor young people in the context of "playful learning and informal exploration," learn about basic business administration, and learn about emerging maker business sectors, (2) opportunities for faculty to engage in research and externships related to the role of makerspaces in the business context of Baltimore City, and (3) space for the CSI DataWorks Baltimore program. (Eichensehr, 2016) Open Works is ingepreneurial by virtue of its focus on community engagement and access, its instruction in entrepreneurship, and its provision of space for innovation.

The CSI will also facilitate the success of aspiring ingepreneurs by serving as a catalyst within the regional ingepreneurial ecosystem. The regional ecosystem includes all entities that have an 
interest in business development. In addition to organizations such as Open Works, stakeholders may include government, schools, other universities, private sector businesses, non-profit organizations, investors, banks, financial institutions, entrepreneurs, community organizations, and students. A July 2010 article in the Harvard Business Review by Daniel Isenburg (2010) titled, "How to Start an Entrepreneurial Revolution," proposes that "entrepreneurs are most successful when they have access to the human, financial and professional resources they need, and operate in an environment in which government policies encourage and safeguard entrepreneurs." This is essentially the climate the CSI will foster for emerging ingepreneurs.

A healthy and productive ingepreneurial environment requires an innovation hub for stakeholders engaging in activities who will promote business development and growth. The ingepreneurship center will be a hub in communities that often lack the vital elements for economic growth. Entities that are not routinely attracted to urban communities with economic indicators well below regional averages will be more likely to coalesce around the activities of an established center associated with an academic institution. The result is a platform for collaboration among institutions within the ingepreneurship ecosystem. The potential for collaboration helps minimize risks and assure organizations that institutional support and engagement will be sufficient for sustained growth.

The structure of the CSI programs will be aligned with the three main components of ingepreneurship: social trajectory, entrepreneurship, and playful ingenuity. One programmatic emphasis includes life skills training that will enable participants to manage personal affairs in a way that will facilitate financial well-being and advancement. There will also be an emphasis on learning and understanding corporate culture.

Experiences that develop entrepreneurial knowledge and skills will be offered in several formats with an emphasis on infusing inventiveness and innovation into all learning activities (Table 3). It is important to utilize sound instructional design practices that are compliant with proven pedagogical and andragogic conventions, such as the Revised Bloom's Taxonomy, to ensure that learning is taking place, while employing creative and project-based learning models to encourage innovation by participants.

Regardless of whether the format is workshops, conferences, or research projects, all activities will include assessment and outcomes-based data on the performance of the CSI and its learning community. The "Play 2 Profit" forums and use of collaborative software will also provide space in which participants are able to collaborate and engage in practical experiences that encourage creativity. Playful ingenuity is a primary catalyst for ingepreneurial effectiveness.

\section{Assessing Ingepreneurial Transformation}

A March 2015 Kaufman Foundation report titled "Measuring an Entrepreneurial Ecosystem" by Dane Stangler and Jordan Bell-Masterson identifies four indicators, each with three measures, by which ecological assessments of entrepreneurial activities can be achieved (Table 4), including 
current programs that are associated with each of the Kaufman measures. The measures may also have implications for determining return on investment within an ingepreneurial ecosystem.

Table 4

CSU Ingepreneurship Activities by Kaufman Measure

\begin{tabular}{|c|c|c|c|}
\hline Indicator & Measure & Possible Sources & Current CSU Activities \\
\hline \multirow[t]{3}{*}{ DENSITY } & $\begin{array}{l}\text { New and young } \\
\text { firms per } 1,000 \\
\text { people }\end{array}$ & $\begin{array}{l}\text { Census Bureau, Business } \\
\text { Dynamics } \\
\text { Statistics (BDS) }\end{array}$ & \multirow{3}{*}{$\begin{array}{l}\text { Data Works @ Open Works } \\
\text { Program (Business } \\
\text { Intelligence Data Program) } \\
\text { Business Innovation } \\
\text { Showcase } \\
\text { Entrepreneurship Certificate } \\
\text { Program } \\
\text { Economic Inclusion } \\
\text { Conference at Coppin } \\
\text { (EICAC) }\end{array}$} \\
\hline & $\begin{array}{l}\text { Share of } \\
\text { employment in } \\
\text { new and young } \\
\text { firms }\end{array}$ & Census Bureau, BDS & \\
\hline & $\begin{array}{l}\text { Sector density, } \\
\text { especially high } \\
\text { tech }\end{array}$ & $\begin{array}{l}\text { National Establishment Time } \\
\text { Series } \\
\text { (NETS) }\end{array}$ & \\
\hline \multirow[t]{3}{*}{ FLUIDITY } & Population flux & Internal Revenue Service & \multirow{3}{*}{$\begin{array}{l}\text { Homeownership Workshops } \\
\text { Economic Inclusion } \\
\text { Conference at Coppin } \\
\text { (EICAC) } \\
\text { Community Walking Labs }\end{array}$} \\
\hline & $\begin{array}{l}\text { Labor market } \\
\text { reallocation }\end{array}$ & $\begin{array}{l}\text { Quarterly Workforce } \\
\text { Indicators (QWI) }\end{array}$ & \\
\hline & $\begin{array}{l}\text { High-growth } \\
\text { firms }\end{array}$ & Inc. 5000 and NETS & \\
\hline \multirow[t]{3}{*}{ CONNECTIVITY } & $\begin{array}{l}\text { Program } \\
\text { connectivity }\end{array}$ & Under development & \multirow{3}{*}{$\begin{array}{l}\text { Economic Inclusion } \\
\text { Conference at Coppin } \\
\text { (EICAC) } \\
\text { Times Community Services } \\
\text { Inc. Speaker Series }\end{array}$} \\
\hline & Spinoff rate & $\begin{array}{l}\text { Possibly: CrunchBase; } \\
\text { LinkedIn }\end{array}$ & \\
\hline & $\begin{array}{l}\text { Dealmaker } \\
\text { networks }\end{array}$ & $\begin{array}{l}\text { Private databases, including } \\
\text { Capital IQ }\end{array}$ & \\
\hline \multirow[t]{3}{*}{ DIVERSITY } & $\begin{array}{l}\text { Multiple } \\
\text { economic } \\
\text { specializations }\end{array}$ & $\begin{array}{l}\text { Quarterly Census of } \\
\text { Employment and Wages } \\
\text { (QCEW) }\end{array}$ & \multirow{3}{*}{$\begin{array}{l}\text { Economic Inclusion } \\
\text { Conference at Coppin } \\
\text { (EICAC) } \\
\text { Global Entrepreneurship } \\
\text { Week Activities }\end{array}$} \\
\hline & Mobility & $\begin{array}{l}\text { Equality of Opportunity } \\
\text { project }\end{array}$ & \\
\hline & Immigrants & $\begin{array}{l}\text { American Community Survey } \\
\text { (ACS) }\end{array}$ & \\
\hline
\end{tabular}


The current CSU activities that directly influence the Kaufman measure are programs such as the: (1) Data Works Program at Open Works (recently granted $\$ 25,00$ from a major financial institution), (2) Certificate in Entrepreneurship, (3) Economic Inclusion Conference at Coppin (EICAC), (4) Global Entrepreneurship Week, (5) Community Walking Labs, (6) Business Innovation Showcase, (7)Volunteer Income Tax Assistance Program (VITA), and (8) CSU Fuel/Renew Youth Ingepreneurship Proposal. This is not an exhaustive list of CSU programs, but represents those that more directly influence the ingepreneurial ecosystem and contribute to the indicators defined by the Kaufman Foundation.

The current density of the West Baltimore community in which Coppin is located provides an indication of the current state of the entrepreneurial ecosystem and a baseline for future progress toward development of ingepreneurs. There are only two businesses in the 21216 postal code that employ between 100 and 249 employees. Sixty-five percent of the employers employ between one and four employees. The average annual payroll of all businesses within the postal code is \$34,519.00 (US Department of Commerce, 2012). Incubation and business development through the CSI will help to increase the commercial activity in the community and ultimately improve all indicators. Measureable outcomes are better assessed when baseline data is readily available.

One of the indicators of entrepreneurial ecosystem vibrancy is "fluidity," which refers to the inflow and outflow of workers and entrepreneurs within a geographic region (Bell-Masterson, 2015). It should be noted that the overall decline of the Baltimore population would generally suggests that the outflow of population has far exceeded the inflow. Recent census data reveals a slight decline in population (The road to 10,000 families, 2015). Entrepreneurial activity helps to balance fluidity by facilitating a cycling of the population that is reflective of fluidity, i.e. new and emerging job opportunities that strengthen the healthy expansion of the ecosystem's capacity and yield.

The measure of connectivity is critical in determining the well-being of the ecosystem. The Kaufman report suggests that "programs, companies, and individuals, and the connectivity between them is another gauge of entrepreneurial vibrancy" (Bell-Masterson, 2015). This presents a tremendous challenge in terms of business partners that are physically located in certain urban neighborhoods like Coppin's. It is important that the connections expand beyond the immediate geographic area. While governmental and corporate partners may not have facilities within close proximity of the University, it is important to extend connections, even if they are at times virtual. Coppin has a demonstrated history with virtual lectures involving industry leaders from around the country.

Diversity of ethnicity, nationality, and industry are just a few indicators that will assist in creating entrepreneurial and ingepreneurial vibrancy. The greatest contributor to diversity is quality of programs. Participants of all backgrounds are attracted to quality that is differentiated from the established norm. The ingepreneurship model is designed to accomplish that goal of excellence in the context of differentiation. The uniqueness of the Coppin State University, its community, and the symbolic value of the "oasis" motif occupied by Coppin sets the university apart. Its institutional uniqueness and legacy contributed to its selection as an anchor institution 
by the Mayor's Office, Baltimore City Anchor Plan. "The Baltimore City Anchor Plan calls on city agencies and local institutions to discuss how they can share goals and resources to address public safety, business and the quality of life in the city" (Green, 2014).

\section{Conclusion}

We are at a pivotal juncture in the social and economic evolution of our nation, particularly regarding the shift from an industrial economy to a techno-informational, service economy. The development and appropriation of labor has not followed the demand. While many economists make assertions about the driving forces (i.e. technology, globalization, the waning influence of unions, etc.), the result is that the bottom $90 \%$ of the population have experienced decline in real income since the 1970s (Kruggman, 2004). This reality is evident in large segments of the population that have not retrained or migrated to meet new workforce demands, particularly in urban areas where manufacturing employment and educational opportunities were plentiful and provided pathways to higher standards of living. Another aspect of this reality is the similarity between the economic disparities in urban areas and rural areas such as Baltimore and the Appalachian region.

The case for strategically building ingepreneurial ecosystems has never been more evident. Those who are well-prepared to fuel an economic resurgence through small business development and growth must be deployed in the economy with the same avidity as educators during the first half of the $20^{\text {th }}$ century. It is this national call to action that will help transform the existing educational infrastructure, entrepreneurial spirit, and sense of community pride into a new system of socioeconomic advancement and prosperity.

Locating the Center for Strategic Ingepreneurship in the heart of the West Baltimore community provides a model that may be replicated in other urban centers. This model presents a unique, comprehensive approach for improving the economies of the areas most devastated by shift away from manufacturing jobs and by the slow pace with which real solutions are emerging. The benefits include, but are not limited to:

1. Restoring the socioeconomic legacy of a growing middle class;

2. Building institutional collaboration between business, academia, and other community stakeholders;

3. Establishing proactive approaches to systemic socioeconomic issues;

4. Developing a new inter-regional model for ingepreneurial development;

5. Leveraging the intellectual credibility of universities that have longstanding and trusted relationships in minority communities;

6. Forming models of assessment that address the uniqueness of struggling communities and commonalities between communities that are not usually compared.

At CSU, current programming includes the CSI Data Works Program at Open Works, the Certificate in Entrepreneurship, the Economic Inclusion Conference at Coppin (EICAC), the Global Entrepreneurship Week activities, the Volunteer Income Tax Assistance Program 
(VITA), the Community Walking Labs for developing West Baltimore business intelligence, the Student Business Innovation Showcase, and the CSU Fuel/Renew Youth Ingepreneurship Proposal. Additional programs are also in the conceptual stage. These program, and our community goodwill established by the 117-year institutional legacy, will enable CSU to continue its contribution to effective community engagement. 


\section{References}

Bates, T. (1993). Banking on the black enterprise: The potential of emerging firms for revitalizing urban economics. Washington, DC: Joint Center for Political and Economic Studies.

Bell-Masterson, J. a. (2015). Measuring an entrepreneurial ecosystem. Kansas City: Ewing Marion Kaufman Foundation.

Boyd, R. (1991). A contextual analysis of black self-employment in large metropolitan areas, 1970-1980. Social Forces, 70, 409-429. http://dx.doi.org/10.1093/sf/70.2.409

Butler, J. (1991). Entrepreneurship and self-help among black Americans: A reconsideration of race and economics. Albany, NY: State University of New York Press.

Chetty, R., \& Hendren, N. (2015). The impacts of neighborhoods on intergenerational mobility: Childhood exposure effects and county-level estimates. Cambridge, MA: National Bureau of Economic Research. Retrieved from http://www.equalityofopportunity.org/images/nbhds_exec_summary.pdf

Chetty, R., Hendren, N., Kline, P., \& Saez, E. (2014). Where is the land of opportunity? The geography of intergenerational mobility in the United States. Cambridge, MA: National Bureau of Economic Research. Retrieved from http://www.nber.org/papers/w19843. http://dx.doi.org/10.1093/qje/qju022

Cheshire, M. (2016). They call me little willie: The life story of William L. Adams. USA: Ellison's Books.

City-Data.com. (2013). 21216 Zip Code Detailed Profile. United States Census. Retrieved from http://www.city-data.com/zips/21216.html\#ixzz3UIsmQmJs

City of Baltimore. (2014). Baltimore City Anchor Plan: A Community and Economic Development Strategy. Retrieved from https://content.govdelivery.com/attachments/MDBALT/2014/06/25/file_attachments/302421/Bal timore\%2BCity\%2BAnchor\%2BPlan\%2B\%2528BCAP\%2529\%2B-\%2BJune\%2B2014.pdf

Commerce, U. S. (2012). 2012 Zip code business patterns (NAICS). Washington D.C.: United States Census Bureau. Retrieved from http://censtats.census.gov/cbpnaic/cbpnaic.shtml

Coppin State University 2013 - 2020 Strategic Plan. Retrieved from http://www.coppin.edu/downloads/file/963/strategic_plan_2013_to_2020

Cremin, L. A. (1959). John Dewey and the progressive-education movement, 1915-1952. The School Review, 160-173. http://dx.doi.org/10.1086/442489

CSU Mission Statement. (n.d.). Coppin State University. Retrieved from http://www.coppin.edu/info/200780/csu_mission_statement 
Davies, C., Gant, N., Hart, A., Millican, J., Wolff, D., Prosser, B., \& Laing, S. (2016). Exploring engaged spaces in community-university partnership. Metropolitan Universities, 27(3), 6-26. Retrieved from https://journals.iupui.edu/index.php/muj/article/view/21377

Eichensehr, M. (2016). Open Works partners with Coppin State on mentorship, entrepreneurship programs. Baltimore Business Journal. Retrieved from

http://www.bizjournals.com/baltimore/news/2016/12/22/openworks-partners-with-coppin-stateon-mentorship.html

Gavazzi, S. (2015). For better and for worse: Understanding optimal campus-community relationships through the lens of marriage. Metropolitan Universities, 26(1), 147-154.

Retrieved from https://journals.iupui.edu/index.php/muj/article/view/20992

Entrepreneurial Life Cycle. (2015). Global Entrepreneurship Institute. Retrieved from http://blog.gcase.org/entrepreneurial-life-cycle/

Great Migration. (2015). Retrieved from History.com: http://www.history.com/topics/blackhistory/great-migration

Green, E. (2014, June 24). City formalizes partnership with local 'anchors'. The Baltimore Sun. Retrieved from http://articles.baltimoresun.com/2014-06-24/news/bs-md-ci-anchor-pledge20140624_1_west-baltimore-city-agencies-bon-secours-hospital

Hewing, M. (2014). Collaboration with potential users for discontinuous innovation: Experimental research on user creativity. Potsdam, Germany: Springer Gabler. http://dx.doi.org/10.1007/978-3-658-03753-6

Isenburg, D. (2010, June). The big idea: How to start an entrepreneurial revolution. Harvard Business Review, 88(6). Retrieved from https://hbr.org/2010/06/the-big-idea-how-to-start-anentrepreneurial-revolution/ar/1

Kasarda, J.D. (1989). Urban industrial transition and the underclass. The Annals of the American Academy of Political and Social Science, 501, 26-47.

http://dx.doi.org/10.1177/0002716289501001002

Kasarda, J.D. (1992). The severely distressed in economically transforming cities. In A. V. Harrell and Ge. Peterson (eds.), Drugs, crime, and social isolation: Barriers to urban opportunity (pp. 45-97). Washington, DC: Urban Opportunity Series, The Urban Institute Press.

John F. Kennedy University. (n.d.). The John F., Kennedy University Story. Retrieved from http://www.jfku.edu/About-Us/The-JFK-University-Story.html\#navigation

Klugh, E. (2016). Displacing community. Anthropology News, 57, 30-31. Retrieved from http://www.anthropology-news.org/index.php/2016/11/21/displacing-community/ 
Krivo, L., \& Peterson, R. D. (2000). The structural contest of homicide: Accounting for racial differences in process. American Sociological Review, 65(4), 547-559.

http://dx.doi.org/10.2307/2657382

Kruggman, P. (2004, January 5). The death of Horatio Alger. The Nation, pp. 16-17.

Lee, M., \& Ousey, G. C. (2005). Institutional access, residential segregation, and urban black homicide. Sociological Inquiry, 75(1), 31-54. http://dx.doi.org/10.1111/j.1475-

682X.2005.00111.x

Levine, M. V. (2000). A Third-World city in the first world. In M. P. Stern, The Social Sustainability of Cities: Diversity and the Management of Change. Toronto: Toronto University Press.

Mause, T. N. (2003, June 23). Bethlehem steel has tight ties to Dundalk. Dundalk Eagle.

MD Alliance of the Poor, M. A. (2014). 2014 Maryland poverty profile. Catholic Charities of Maryland. Retrieved from http://www.catholiccharities-md.org/public-policy/2014-map-povertyprofiles.pdf

Myers, M. (2001). Coal Mechanization and Migration from McDowell County, West Virginia, 1932-1970. East Tennessee State University. Electronic Theses and Dissertations. Paper 116. Retrieved from http://dc.etsu.edu/etd/116

Parker, K. (2004). Industrial shift, polarized labor markets, and urban violence: Modeling the dynamics between the economic transformation and disaggregated homicide. Criminology, 42(3), 619-644. http://dx.doi.org/10.1111/j.1745-9125.2004.tb00531.x

Parker, K. (2015). The African-American entrepreneur-crime drop relationship: Growing African-American business ownership and declining youth violence. Urban Affairs Review, 51, 751-780. http://dx.doi.org/10.1177/1078087415571755

Parker, K. \& McCall, P. (1999). Structural conditions and racial homicide patterns: A look at the multiple disadvantages in urban areas. Criminology, 37(3), 711-735.

https://doi.org/10.1111/j.1745-9125.1999.tb00493.x

Regional Research Institute, School of Social Work, Portland State University. (2017).

Wraparound Basics: What is Wraparound? National Wraparound Initiative. Retrieved from http://nwi.pdx.edu/wraparound-basics/\#isWraparoundevidence

Robb, A., \& Fairlie, R. (2009). Access to financial capital among U.S. businesses: The case of African American firms. The Annals of the American Academy of Political and Social Sciences, 613, 47-72. https://dx.doi.org/10.1177/0002716207303578

Rodman, N. (2012, February 29). Honoring history and education. Retrieved from http://www.dundalkeagle.com/component/content/article/2-slideshow/39962-honoring-historyand-education. 
Rodwell, G., \& Klugh, E. (2014). Collaborative constructions: Constituency, power, and engagement. Metropolitan Universities, 25(2), 72-88. Retrieved from https://journals.iupui.edu/index.php/muj/article/view/20574

The road to 10,000 families. (2015, March 27). The Baltimore Sun.Retrieved from http://www.baltimoresun.com/news/opinion/editorial/bs-ed-baltimore-population-20150327story.html

Wilson, W. J. 1987. The truly disadvantaged: The inner city, the underclass and public policy. Chicago: Univ. of Chicago Press.

Wilson, W. J. 1996. When work disappears: The world of the new urban poor. New York: Alfred A. Knopf. 


\section{Author Information}

Ronald Williams is the Interim Dean of the Coppin State University College of Business. He received his Ph.D. in management and organization from George Washington University in Washington, D.C with concentrations in organization behavior and development and the management of science, technology and innovation. Under his leadership, the CSU College of Business was named as one of the 2015 Top 50 Small Business Programs in the country by the Business Resource Guide.

Ronald C. Williams, Ph.D.

Interim Dean, College of Business

Coppin State University

Coppin State University

2500 W. North Avenue

Baltimore, MD 21216

E-mail: rwilliams@coppin.edu

Telephone: 410-951-3452

Fax: 410-951-3487

Elgin Klugh is an Associate Professor in the Department of Criminal Justice \& Applied Social and Political Sciences at Coppin State University in Baltimore, MD. An Urban Anthropologist, his primary areas of interest include Community Revitalization, Cultural Landscapes, Heritage, and African American History and Culture.

Elgin L. Klugh, Ph.D. (Corresponding Author)

Associate Professor

Criminal Justice \& Applied Social and Political Sciences

Coppin State University

$2500 \mathrm{~W}$. North Avenue

Baltimore, MD 21216

E-mail: eklugh@ coppin.edu

Telephone: 410-951-3529

Fax: 410-951-3045 